\title{
Effect of Wasabi Leafstalk (Wasabia japonica MATSUM.) Extract on Bone Metabolism in Mouse Calvaria Tissue Culture
}

\author{
Toshihiro SuzUKI, ${ }^{1}$ Hiroshi NAKAYAMA ${ }^{1}$ and Masayoshi YAMAGUCHI ${ }^{2}$ \\ ${ }^{1}$ Food and Chemical Technology Department, Shizuoka Industrial Research Institute of Shizuoka Prefecture, 2078 Makigaya, \\ Shizuoka 421-12, Japan \\ ${ }^{2}$ Laboratory of Endocrinology and Molecular Metabolism, Graduate School of Nutritional Sciences, University of Shizuoka, 52-1 \\ Yada, Shizuoka 422, Japan
}

Received April 2, 1997; Accepted August 19, 1997

\begin{abstract}
The effect of wasabi leafstalk (Wasabia japonica MATSUM.) extract on bone metabolism in a tissue culture system using mouse calvaria in vitro was investigated. The calvaria tissues obtained from normal mice were cultured for $48 \mathrm{~h}$ at $37^{\circ} \mathrm{C}$ in $5 \% \mathrm{CO}_{2} / 95 \%$ air in Dulbecco's modified Eagle's medium (high glucose, $4.5 \mathrm{~g} / \mathrm{dl}$ ) containing either vehicle or wasabi leafstalk extract $(10,50$ and $250 \mu \mathrm{g} / \mathrm{ml}$ of medium). Wasabi leafstalk extract was obtained from a homogenate with $20 \%$ ethanol. The presence of wasabi leafstalk extract $(10 \mu \mathrm{g} / \mathrm{ml}) \mathrm{caused}$ a significant increase in calcium content and alkaline phosphatase activity in the bone tissues. With higher concentrations (50 and $250 \mu \mathrm{g} / \mathrm{ml})$, however, the effect was weakened. The bone deoxyribonucleic acid (DNA) content was not significantly altered by the presence of wasabi leafstalk extract $(10$ and $50 \mu \mathrm{g} / \mathrm{ml})$. The wasabi leafstalk extract-induced increase in bone calcium content was completely prevented by the coexistence of cycloheximide $\left(10^{-6} \mathrm{M}\right)$, an inhibitor of protein synthesis, suggesting that the effect of wasabi leafstalk extract is based on a newly synthesized protein component. Meanwhile, the anabolic effect on bone calcium content was not seen in the presence of the ethanol extract $(50 \mu \mathrm{g} / \mathrm{ml})$ from loquat leaf, cherry leaf, dried shiitake, gabaron tea, green tea (sencha), muskmelon, satsuma mandarin, tomato, blueberry, and soy bean. The present study demonstrates that wasabi leafstalk extract has an anabolic effect on bone calcification, in vitro.
\end{abstract}

Keywords: bone metabolism, wasabi leafstalk, calcium, alkaline phosphatase, mouse calvaria

It is known that bone mass decreases in both men and women with increasing age. The decrease in bone mass may be due to increased bone resorption or to decreased bone formation (Nishimoto et al., 1985). Ovarian hormone deficiency at menopause stimulates bone loss. Current hypotheses have linked ovarian hormone deficiency to a defect in the calcium and bone regulatory actions of the calcitropic hormones, calcitonin, 1,25-dihydroxyvitamin $\mathrm{D}_{3}$, and parathyroid hormone (Gray, 1981; Ishida et al, 1987; Morimoto et al., 1979; Kalu et al., 1989). Moreover, the alteration in bone cell function with increasing age may be caused (Yamaguchi, 1994).

Recently, it has been demonstrated that bone formation deteriorates with increasing age, and that the deterioration is partly restored by the oral administration of zinc, an essential trace element, which can stimulate bone formation (Yamaguchi et al., 1987, 1994) in aged rats (Yamaguchi \& Ozaki, 1990). More recently, it has been demonstrated that the effect of vitamin $\mathrm{K}_{2}$ (menaquinone-7) on trabecular bone calcification in rats with skeletal unloading-induced osteopenia is enhanced by zinc in vitro; the enhancement with zinc may be based on a newly synthesized protein in the bone tissues (Ehara et al. 1996). Thus, the nutrient factors may play a role in the regulation of bone cell function which is altered by aging.

However, the nutrient factors which can act on bone metabolism have been clarified fully. The identification of nutrient factors may be important in the prevention of osteoporosis with increasing age. Therefore, the present study was undertaken to determine the effect of plant and food extracts on bone metabolism. An attempt was made to search for plants and foods which can affect bone using a tissue culture system in vitro. We chose some plants and foods which are produced in the area of Shizuoka Prefecture. It was found that, of various plant and food extracts, wasabi leafstalk (Wasabia japonica MATSUM.) has a stimulatory effect on the calcium content in mouse calvaria in vitro.

\section{Materials and Methods}

Chemicals Dulbecco's modified Eagle's medium (high glucose, $4.5 \mathrm{~g} / \mathrm{dl}$ ) and a penicillin-streptomycin solution ( $5000 \mathrm{U} / \mathrm{ml}$ penicillin; $5000 \mu \mathrm{g} / \mathrm{ml}$ streptomycin) were obtained from Gibco Laboratories (Grand Island, N.Y., USA). Bovine serum albumin (fraction $\mathrm{V}$ ) and cycloheximide were obtained from Sigma Chemical (St. Louis, Mo., USA). Other chemicals were reagent grade from Wako Pure Chemical Industries (Osaka).

Plant extracts Fresh wasabi leafstalk (Wasabia japonica MAtsuM.; about $50 \mathrm{~g}$ ) was homogenized for $3 \mathrm{~min}$ in distilled water or $20 \%$ ethanol solution $(150 \mathrm{ml})$, and the homogenate was centrifuged at $8000 \mathrm{rpm}$ for $20 \mathrm{~min}$. The resulting supernatant was filtered through filtration paper, and then the filtration solution was extracted 3 times with ethyl ether (about $150 \mathrm{ml}$ ). The ether phase was removed, and 
the resulting aqueous phase was dried by freezing. About $0.9 \mathrm{~g}$ of the frozen powder were obtained. The powder was dissolved in $15 \%$ ethanol solution. Before its use in the bone culture experiments, $15 \%$ ethanol wasabi leafstalk extract was aseptically filtered through a membrane filter. Similarly, other extract samples were obtained from many plants and foods.

Animals Male Ddy mice (4 weeks old) were obtained from Japan SLC (Hamamatsu). The five animals in each group were fed commercial laboratory chow (solid) containing $57.4 \%$ carbohydrate, $1.1 \% \mathrm{Ca}$, and $1.1 \% \mathrm{P}$ at a room temperature of $25^{\circ} \mathrm{C}$ and were given distilled water freely.

Bone culture The mice were sacrificed by decapitation under light anesthesia with ether. The calvarial tissues were removed aseptically and cut along the sagittal suture into left and right halves. One-half of each calvarium served as a control for its paired, treated half. Calvaria fragments were cultured for $48 \mathrm{~h}$ in a $35-\mathrm{mm}$ dish in $2.0 \mathrm{ml}$ medium consisting of Dulbecco's modified Eagle's medium (high glucose, $4.5 \mathrm{~g}$ / dl) supplemented with $0.25 \%$ bovine serum albumin plus antibiotics (100 U penicillin and $100 \mu \mathrm{g}$ streptomycin $/ \mathrm{ml}$ of medium) (Yamaguchi et al., 1987). Cultures were maintained at $37^{\circ} \mathrm{C}$ in a water-saturated atmosphere containing $5 \% \mathrm{CO}_{2}$ and $95 \%$ air. In the experiments, the culture medium contained wasabi leafstalk extract $(10,50$ and $250 \mu \mathrm{g} / \mathrm{ml})$ or other plant extracts $(10-250 \mu \mathrm{g} / \mathrm{ml})$ in the absence or presence of cycloheximide $\left(10^{-6} \mathrm{M}\right)$.

Analytical procedures The calvaria tissues were dried for $16 \mathrm{~h}$ at $110^{\circ} \mathrm{C}$, weighed, and then digested with nitric acid $(2.0 \mathrm{ml})$ for $12 \mathrm{~h}$ at $120^{\circ} \mathrm{C}$. Calcium was determined by atomic absorption spectrophotometry (Yamaguchi et al., 1987). The calcium content was expressed as mg per g dry bone.

To assay alkaline phosphatase activity, the bone tissues were immersed in $3.0 \mathrm{ml}$ ice-cold $6.5 \mathrm{~mm}$ barbital buffer $(\mathrm{pH}$ 7.4), cut into small pieces, homogenized with a physcotron homogenizer, and disrupted for $60 \mathrm{~s}$ with an ultrasonic device. The supernatant was centrifuged at $600 \times g$ for $5 \mathrm{~min}$ and used to measure the enzyme activity. Enzyme assay was carried out under optimal conditions. Alkaline phosphatase activity was determined by the method of Walter and Schutt (1965). Enzyme activity was expressed as $\mu \mathrm{mol}$ of $p$-nitrophenol liberated per min per mg protein. Protein concentration was determined by the method of Lowry et al. (1951).

To measure bone DNA content, the bone tissues were shaken with $4.0 \mathrm{ml}$ of ice-cold $0.1 \mathrm{~N} \mathrm{NaOH}$ solution for $24 \mathrm{~h}$ after the homogenization of the bone tissue (Flanagan \& Nichols, 1962). After alkali extraction, the samples were centrifuged at $10000 \times g$ for $5 \mathrm{~min}$, and the supernatant was collected. DNA content in the supernatant was determined by the method of Ceriotti (1955) and expressed as the amount $(\mathrm{mg})$ of DNA per $\mathrm{g}$ wet weight of bone tissue.

Statistical analysis The significance of difference between values was estimated by the Student's $t$-test. $p$ Values of less than 0.05 were considered to show statistically significant differences. Also, we used a multi-way ANOVA using a Duncan's post hoc test to compare the treatment groups.

\section{Results}

The effect of $20 \%$ ethanol extracts obtained from various plants and foods on bone calcium content was examined, and the results are shown in Fig. 1. Calvaria tissues from mice were cultured for $48 \mathrm{~h}$ in the medium containing either vehicle $(0.15 \%$ ethanol) or plant extract. The ethanol extracts ( $50 \mu \mathrm{g} / \mathrm{ml}$ of medium) from katsuo-bushi (dried bonito), loquat leaf, cherry leaf, dried shiitake, raw shiitake, Gabaron tea, green tea (sencha), muskmelon, Satsuma mandarin, tomato, blueberry, and soy bean did not have the effect of increasing the bone calcium content. However, the presence of wasabi leafstalk extract in the culture medium caused an elevation of the bone calcium content.

The effect of increasing concentrations of the ethanol extracts from green tea, gabaron tea, muskmelon, and wasabi leafstalk was examined. The presence of green tea extract in the bone culture medium $(5,50$ and $500 \mu \mathrm{g} / \mathrm{ml})$ caused a decrease in bone calcium content (data not shown). Gabaron

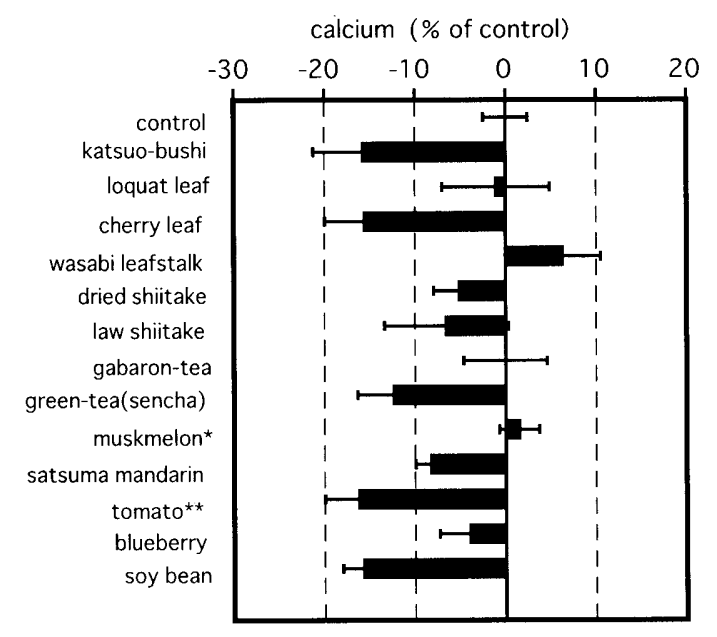

Fig. 1. Effect of food extracts on calcium content in the calvaria tissues of mice in vitro. Mouse calvaria tissues were cultured for $48 \mathrm{~h}$ in the medium containing either vehicle or various food extracts $(50 \mu \mathrm{g} / \mathrm{ml}$ of medium). Each value represents the mean \pm SEM of five bone tissues from different animals. Bone calcium content in the control group was $170.4 \pm 3.8(\mathrm{mg} / \mathrm{g}$ dry bone). *Picked immature melon fruit. **Highly soluble solid tomato.

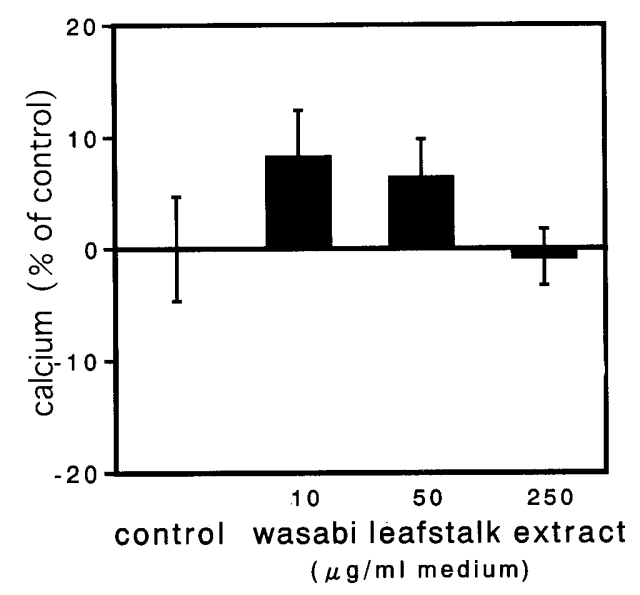

Fig. 2. Effect of increasing concentrations of wasabi leafstalk extract on calcium content in the calvaria tissues of mice in vitro. Mouse calvaria tissues were cultured for $48 \mathrm{~h}$ in the medium containing either vehicle or wasabi leafstalk extract (10,50 and $250 \mu \mathrm{g} / \mathrm{ml}$ of medium). Each value represents the mean \pm SEM of five bone tissues from different animals. 
tea extract $(10 \mu \mathrm{g} / \mathrm{ml})$ slightly increased bone calcium content, although such an effect was not seen with the 50 and 150 $\mu \mathrm{g} / \mathrm{ml}$ concentrations (data not shown). Muskmelon extract (10, 50 and $250 \mu \mathrm{g} / \mathrm{ml}$ ) elevated bone calcium content, but the effect was not significant (data not shown). Meanwhile, wasabi leafstalk extract had an appreciable effect on increasing bone calcium content; the effect was greater at the $10 \mu \mathrm{g}$ / $\mathrm{ml}$ than at the $50 \mu \mathrm{g} / \mathrm{ml}$ (Fig. 2). With the higher concentration of $250 \mu \mathrm{g} / \mathrm{ml}$, the wasabi leafstalk extract had no effect. Thus, wasabi leafstalk had an unique anabolic effect on bone calcium.

The effect of wasabi leafstalk extract in the presence of muskmelon which can slightly increase bone calcium content was examined. Calvaria tissues were cultured for $48 \mathrm{~h}$ in the medium containing either vehicle, wasabi leafstalk extract ( 10 $\mu \mathrm{g} / \mathrm{ml})$, muskmelon extract $(10 \mu \mathrm{g} / \mathrm{ml})$ or wasabi leafstalk extract $(10 \mu \mathrm{g} / \mathrm{ml})$ plus muskmelon extract $(10 \mu \mathrm{g} / \mathrm{ml})$. The effect of wasabi leafstalk extract on increasing the bone calcium content was not seen in the presence of muskmelon (Table 1). Thus, the combination of wasabi leafstalk and muskmelon extracts did not have an additive effect on bone calcium content.

The effect of wasabi leafstalk extract on bone calcium content in the presence of cycloheximide is shown in Fig. 3.

Table 1. Effect of wasabi leafstalk and muskmelon extract on calcium content in the calvaria tissues of mice in vitro.

\begin{tabular}{lc}
\hline Treatment & Calcium content $(\mathrm{mg} / \mathrm{g}$ dry bone $)$ \\
\hline Control & $173.1 \pm 2.70$ \\
Wasabi leafstalk $(10 \mu \mathrm{g} / \mathrm{ml})$ & $187.7 \pm 4.72^{*}$ \\
Muskmelon $(10 \mu \mathrm{g} / \mathrm{ml})$ & $179.2 \pm 2.81$ \\
Wasabi leafstalk + Muskmelon & $178.3 \pm 5.34$ \\
\hline
\end{tabular}

Mouse calvaria tissues were cultured for $48 \mathrm{~h}$ in the medium containing either vehicle, wasabi leafstalk, muskmelon or wasabi leafstalk plus muskmelon. Each value represents the mean \pm SEM of eight to eleven bone tissues from different animals. ${ }^{*} p<0.025$, compared with the control value.

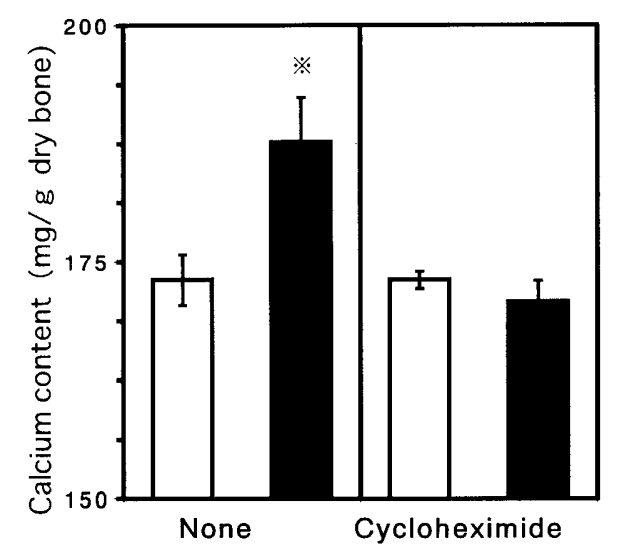

Fig. 3. Effect of cycloheximide on the wasabi leafstalk extract-increased calcium content in the calvaria tissues of mice in vitro. Mouse calvaria tissues were cultured for $48 \mathrm{~h}$ in the medium containing either vehicle or wasabi leafstalk extract ( $10 \mu \mathrm{g} / \mathrm{ml}$ of medium) in the absence or presence of cycloheximide $\left(10^{-\dot{b}} \mathrm{M}\right)$. Each value represents the mean \pm SEM of five bone tissues from different animals. ${ }^{*} p<0.025$, compared with the control value. $\square$, control; $\mathbf{\square}$, wasabi leafstalk extract.
Calvaria tissues were cultured for $48 \mathrm{~h}$ in the medium containing either vehicle, wasabi leafstalk extract $(10 \mu \mathrm{g} / \mathrm{ml})$, cycloheximide $\left(10^{-6} \mathrm{M}\right)$ or wasabi leafstalk extract $(10 \mu \mathrm{g} /$ $\mathrm{ml})$ plus cycloheximide $\left(10^{-6} \mathrm{M}\right)$. The effect of wasabi leafstalk extract to increase bone calcium content was completely abolished by the presence of cycloheximide, an inhibitor of protein synthesis.

The effect of wasabi leafstalk extract on bone alkaline phosphatase activity and bone DNA content was also examined. Calvaria tissues were cultured for $48 \mathrm{~h}$ in the presence of wasabi leafstalk extract ( 10 and $25 \mu \mathrm{g} / \mathrm{ml})$. Bone alkaline phosphatase activity was significantly $(p<0.01)$ increased by the presence of wasabi leafstalk extract $(10 \mu \mathrm{g}$ / $\mathrm{ml}$ ) (Fig. 4). However, an appreciable effect was not seen in the presence of $25 \mu \mathrm{g} / \mathrm{ml}$, although the enzyme activity was increased in comparison with that of control. Meanwhile, bone DNA content was not significantly altered by the pre-

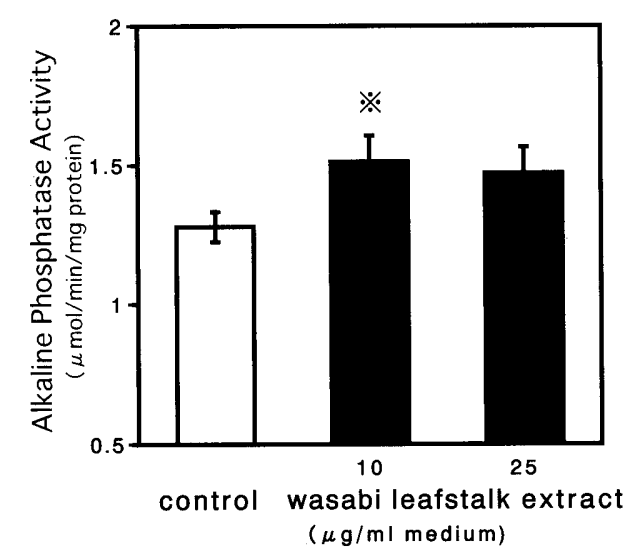

Fig. 4. Effect of wasabi leafstalk extract on alkaline phosphatase activity in the calvaria tissues of mice in vitro. Mouse calvaria tissues were cultured for 48 $\mathrm{h}$ in the medium containing either vehicle or wasabi leafstalk extract ( 10 and $25 \mu \mathrm{g} / \mathrm{ml}$ of medium). Each value represents the mean \pm SEM of five bone tissues from different animals. ${ }^{*} p<0.01$, compared with the control value.

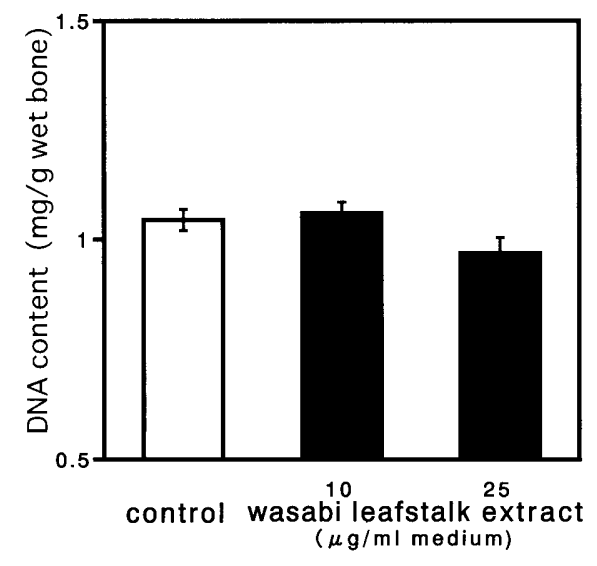

Fig. 5. Effect of wasabi leafstalk extract on DNA content in the calvaria tissues of mice in vitro. Mouse calvaria tissues were cultured for $48 \mathrm{~h}$ in the medium containing either vehicle or wasabi leafstalk extract ( 10 and $25 \mu \mathrm{g} / \mathrm{ml}$ of medium). Each value represents the mean \pm SEM of five bone tissues from different animals. 
sence of wasabi leafstalk extracts ( 10 and $25 \mu \mathrm{g} / \mathrm{ml}$ ) (Fig. 5).

Moreover, the water extracts from wasabi leafstalk homogenate had an appreciable effect on increasing the bone calcium content. This effect was equal to that of $20 \%$ ethanol extract from wasabi leafstalk homogenate (data not shown). Addition of those extracts into the culture medium did not cause an elevation of calcium concentration in the culture medium; the increase was slight i.e., only 0.39 or $0.49 \mu \mathrm{g} / \mathrm{ml}$ of medium, respectively. Such an elevation did not influence the net amount of bone calcium content.

\section{Discussion}

Of various plant and food extracts, wasabi leafstalk extract had a unique stimulatory effect on calcium content in the calvaria tissues of mice in vitro. The presence of wasabi leafstalk extract in the culture medium caused a significant increase in bone alkaline phosphatase activity which is involved in the promotion of bone calcification. Moreover, the wasabi leafstalk extract-increased bone calcium content was completely abolished by the presence of cycloheximide, an inhibitor of protein synthesis. These results suggest that the effect of wasabi leafstalk extract of increasing bone calcium content may be based on a newly synthesized protein component. However, wasabi leafstalk extract did not have an appreciable effect on bone DNA content, suggesting that the extract does not stimulate the proliferation on bone cells in vitro.

Wasabi leafstalk extract contained only a slight amount of calcium. This calcium content did not influence bone calcification. Moreover, the extract did not contain the trace element zinc, which can stimulate bone formation and calcification (Yamaguchi et al., 1987), indicating that the effect of wasabi leafstalk extract does not result from the metal ion in the extract. Meanwhile, the increasing concentrations of wasabi leafstalk extract weakened the effect of the extract to stimulate bone calcification. This may suggest that a great amount of wasabi leafstalk extract reveals a toxic effect on bone cells (osteoblasts). Presumably, the smaller amount of wasabi leafstalk extract has a useful component which stimulates bone calcification. Heat treatment (for $15 \mathrm{~min}$ at $100^{\circ} \mathrm{C}$ ) of wasabi leafstalk extract had a stimulatory effect on bone calcium content (data not shown), suggesting that the protein component in the extract is not involved in the effect. The isolation of the active component in wasabi leafstalk extract remains to be done.

Bone mass decreases with increasing age, and this induces osteoporosis (Nishimoto et al., 1985; Gray, 1981; Ishida et al., 1987; Morimoto et al, 1979; Kalu et al., 1989). The nutritional factors which can prevent osteoporosis have not been fully known (Yamaguchi, 1994). Recently, it has been demonstrated that zinc and vitamin $\mathrm{K}_{2}$ have a stimulatory effect on bone formation and mineralization (Yamaguchi, 1994; Ehara et al, 1996). Zinc has a potent effect on bone formation and mineralization compared with the vitamin $\mathrm{K}_{2}$ effect (Ehara et al, 1996). Wasabi leafstalk extract did not have an appreciable effect on bone DNA content, suggesting that the extract does not influence bone cell proliferation. However, wasabi leafstalk extract may contain a useful component for the prevention of osteoporosis. Further studies are in progress to clarify the effect of wasabi leafstalk extract on bone metabolism in vivo using an animal model.

In conclusion, it has been demonstrated that wasabi leafstalk extract contains the components to stimulate bone calcification in a tissue culture system in vitro. Of various plant and food extracts used, wasabi leafstalk extract may have a unique effect on bone calcification.

\section{References}

Ceriotti, G. (1955). Determination of nucleic acids in animals tissues. J. Biol. Chem., 214, 39-77.

Ehara, Y., Takahashi, H., Hanahisa, Y. and Yamaguchi, M. (1996). Effect of vitamin $\mathrm{K}_{2}$ (menaquinone-7) on bone metabolism in the femoral-metaphyseal tissues of normal and skeletal-unloaded rats: enhancement with zinc. Res. Exp. Med., 196, 171-178.

Flanagan, B. and Nichols, G., Jr. (1962). Metabolic studies of bone in vitro. IV. Collagen biosynthesis by surviving bone fragments in vitro. J. Biol. Chem., 237, 3786-3792.

Gray, R.W. (1981). Effects of age and sex on the regulation of plasma $1,25-(\mathrm{OH})_{2} \mathrm{D}_{3}$ by phosphorus in the rat. Calcif. Tissue Int., 33, 477484.

Ishida, M., Bulos, B., Takamoto, S. and Sacktor, B. (1987). Hydroxylation of 25-hydroxyvitamin $D_{3}$ by renal mitochondria from rats of different ages. Endocrinology, 121, 443-448.

Kalu, D.N., Liu, C-C., Hardin, R.R. and Wollis, B.W. (1989). The aged rats model of ovarian hormone deficiency bone loss. Endocrinology, 124, 7-16.

Lowry, O.H., Rosebrough, N.J., Farr, A.L. and Randall, R.J. (1951). Protein measurement with the Folin phenol reagent. J. Biol. Chem., 193, 265-273.

Morimoto, S., Onishi, T., Okada, T. and Kuwahara, Y. (1979). Comparison of human calcitonin secretion after a 1-minute calcium infusion in young normal and elderly subjects. Endocrinol. Jpn., 26, 207-211.

Nishimoto, S.K., Chang, C-H., Gendler, E., Stryker, W.F. and Nimi, M.E. (1985). The effect of aging on bone formation in rats: biochemical and histological evidence for decreased bone formation capacity. Calcif. Tissue Int., 37, 617-624.

Walter, K. and Schutt, C. (1965). Acids and alkaline phosphatase in serum. In "Methods of Enzymatic Analysis," Vol. 1 and 2, ed. by H.V. Bergmeyer. Academic Press, New York, pp. 856-860.

Yamaguchi, M. (1994). Alteration of bone metabolism: effect of nutrition. In "Pathology of the Aging Rat," ed. by U. Mohr, D.L. Dungworth and C.C. Capen. ILSI Press, Washington, D.C., USA, pp. 499-511.

Yamaguchi, M., Kishi, S. and Hashizume, M. (1994). Effect of zincchelating dipeptides on osteoblastic MC3T3-El cells: activation of aminoacyl-tRNA synthetase. Peptides, 15, 1367-1371.

Yamaguchi, M., Oishi, H. and Suketa, Y. (1987). Stimulatory effect of zinc on bone formation in tissue culture. Biochem. Pharmacol., 36, 4007-4012.

Yamaguchi, M. and Ozaki, K. (1990). Aging affects cellular zinc and protein synthesis in the femoral diaphysis of rats. Res. Exp. Med., 190, 295-300. 